\title{
Teaching (Theoretical) Linguistics in the Second Language Classroom: Beyond Language Improvement
}

\author{
Maite Correa \\ Colorado State University
}

Received: 13 July 2012 / Accepted: 7 February 2013

ISSN: $1697-7467$

\begin{abstract}
Linguistics enjoys a paradoxical place in second language (SL) teaching. Unlike students majoring in Linguistics who see it as "study of the mind", those who take it as part of a language degree see it as relevant as far as it supports language learning. However, a good command of the language is not sufficient for effective teaching. I address the need to revise the place of linguistics in SL curricula and present an innovative teaching approach that analyzes language in a scientific, systematic manner while focusing on those aspects of language that are of direct relevance to future language teachers.

Keywords: Theoretical linguistics, pedagogy, teacher education, teacher learning, educational linguistics.

La enseñanza de lingüística (teórica) en la clase de ELE: más allá de la mejora comunicativa

RESUMEN: La lingüística ocupa un lugar paradójico en los departamentos de didáctica de la lengua extranjera: aunque en los departamentos de Filología se ve como una "ventana a la mente", en los de didáctica se ve como un apoyo al aprendizaje de la lengua por parte del futuro profesor. En este artículo reviso el lugar de la lingüística en el currículo de enseñanza de segundas lenguas y presento un enfoque a la enseñanza de la lingüística que, siendo sistemático y científico, también se enfoca en aquellos aspectos relevantes para los futuros maestros de lengua extranjera.

Palabras clave: Lingüística teórica, pedagogía, formación del profesorado, desarrollo profesional del docente, lingüística educacional.
\end{abstract}

\section{INTRODUCTION}

(Theoretical) linguistics holds a contradictory place in second/foreign language departments: For language majors, courses in this discipline are required together with other "content" courses (traditionally culture and literature). However, and unlike linguistics majors in English who see the study of language as "study of the mind", those who take it as an obligatory component within a language degree see it as relevant in as far as it supports the language learning process (Correa, 2011; Treffers-Daller, 2003), which is logical if we take into account that the great majority of language majors has teaching (and not being linguists) as their primary career objective (Hudson, 2003). As a consequence, most of the 
linguistics courses they are usually required to take in order to get an additional teaching certification are on language pedagogy and not on linguistic theory.

Any language teacher with experience would agree that a good command of the language is not enough for effective teaching (Cravens, 1996; Ellis, 2012; Freeman and Johnson, 1998; Phillipson, 1992), but neither is a vast knowledge of linguistic theory (Widdowson, 2000; $\mathrm{Wu}, 1992)$. My position is aligned with that of Johnston and Goettsch's (2000), who claim that future language teachers must be trained in at least three areas that are intimately intertwined: 1) content (theoretical linguistics), 2) pedagogical content (language pedagogy or methods courses), and 3) second language acquisition theory (applied linguistics). The ACTFL Program Standards for the Preparation of Foreign Language Teachers mandate for teachers to not only be highly proficient in the language (Standard 1a), but also to "know the linguistic elements of the target language system, recognize the changing nature of language, and accommodate for gaps in their own knowledge of the target language system" (Standard 1b: 3). The rationale for such a claim is that this theoretical knowledge, which encompasses most areas of what is taught in an introductory Linguistics course (phonology, morphology, syntax, sociolinguistics, pragmatics...) will enable teacher candidates to "organize instruction, diagnose their students' linguistic difficulties, and assist them in understanding linguistic concepts" (2002: 13).

In this article I examine the place of theoretical linguistics courses in second/foreign language (SL/FL) curricula: is linguistics a science or an art? What is the purpose of linguistics courses for language majors whose main objective is to teach the language? What would this objective be if their career objective is not to teach? And if they are not language majors?

Additionally, I will present an innovative, "user-friendly" teaching approach that looks at language in a scientific, systematic manner while at the same time focuses on those aspects of language that are of direct relevance not only to language majors, but also to students in any area related to the humanities, social sciences or education.

\section{Linguistics: Science or Art?}

Linguistics is a discipline that oftentimes falls into at least two very different categories (Petray, 2004): While theoretical linguistics is usually considered as a discipline within the social/behavioral sciences, language pedagogy is usually thought about as educational in nature. When we add the second language component, we see that linguistics courses taught in the target language are hosted in language departments, which are usually part of humanities or liberal arts colleges. From the perspective of the language major it makes sense: since the other language, literature and culture courses they are taking also belong to the arts, so should linguistics. However, the paradox is that, while a phonetics \& phonology course taught in English will probably be in the college of social sciences, the same course taught in German at the same institution can belong in the college of humanities.

This apparent inconsistency is not such when we look into the nature of what language and language study encompass. Ives already claimed half a century ago that, while "the study of the forms of language is a science[,] the proper and effective use of language is an art" (1955: 165). In fact, and although we cannot simply detach ourselves from the 
human component of language, we cannot forget either that our method of looking at it is, in many ways, scientific:

[L]anguage is simultaneously the stuff of art - the fabric of which poetry is wrought - and a puzzle for social and biological science. It spans the alleged gulf between the humanities and the sciences $[\ldots]$ perhaps the only subject that regularly gets research funding from agencies in the humanities, the social sciences and the natural sciences (Pullum, 1991: 27).

\section{LINGUISTICS FOR NON-LINGUISTS}

The main and most obvious difference between linguistics courses in linguistics departments and linguistics courses in language departments is that the former are taught in the first language while the latter are taught in the target language. This difference in language of instruction brings with it very important implications when designing and implementing the course: at this point (junior or senior) students are expected to be "fully in control" of the language (Partington, 1992: 2). However, the reality is that, after only six or seven semesters of language instruction, students are very limited in what they can do with the language (making grammaticality judgments, discern among different allophones or simply understanding a theoretical linguistics text in the target language).

The second main difference between these two types of courses is that the main aim of the language major is rarely to be a linguist:

[S]tudents who have chosen to major in Linguistics [...] are much more focused on Linguistics than students who take it as an obligatory component in a degree which focuses on Languages. Perhaps it is fair to say that Languages students study Linguistics in order to better understand Spanish/French or German whereas Linguistics students study English/Spanish/French/German in order to understand more of the nature of language in general and more of theories that explain language competence or performance (Treffers-Daller, 2003: 13).

As a consequence, the introductory linguistics course is usually "the first, last, and only linguistics course that most [language] undergraduates will take" (Spring et al., 2000: 110), which leaves the instructor with a dilemma: what should the main objective of this course be? It would seem unrealistic to teach Optimality Theory or the Minimalist Program to a student who might very likely have grammatical/phonological problems herself and/or does not intend to be a linguist, but, at the same time it would be unfair to expect a course in linguistics to merely serve the purpose of increasing proficiency in the language:

Students of language and neophyte language teachers are, indeed, very fond of talking and thinking about language, yet it is possible to complete not just a BA in a language department, but the entire sequence through doctoral studies, and still remain remarkably unknowledgeable about language in general and Italian (or German, French, etc.) in particular (Cravens, 1996: 465) 
As we can appreciate here, we need to re-evaluate what we want our students to take from very probably, the only linguistics course they will ever take. I hereby propose the development of three different types of linguistics for non-linguists courses: a course for language majors, a course for language teachers, and an additional one for humanities/social sciences students.

\subsection{Linguistics for Language Majors (non-Teachers)}

As it has already been discussed above, it seems clear that 1) a traditional linguisticsfor-linguists course is not going to be useful or even positive for a language major, and that 2) the main aim of a linguistics-for-non-linguists course should go far beyond instructing L2 learners in the language. As Treffers-Daller suggests, these courses should include "those areas of Linguistics which help them to reflect upon the process of language learning itself" (2003: 14), and distance themselves from traditional, superficial, previously-learned prescriptive grammar content:

[A]ny attempt to look at language in a scientific way is in tension with school grammar and other such sorts of language mythologizing not subject to scientific explanation: prescriptive notions about language use; the conviction that the real object of the study of grammar is writing, thus equating knowledge of language with writing and reading skills; the view that certain varieties of a language or certain languages are esthetically, logically, or in some way superior to others; and so on (O'Neil, 1998: 12).

In this regard, our linguistics courses should depart from what students have learned in their previous language courses and begin by deconstructing the presupposition that prescriptive forms should (and do) prevail in native-like language use. I propose that this reflection be anchored in observations about the prescriptive and non-prescriptive uses of their own L1 and the appropriateness or acceptability of each of these forms in different situational contexts. This way, while drawing their attention to the natural occurrence of non-prescriptive forms in their own language, language majors would gain understanding of the relative value of learning to use and understand both prescriptive and non-prescriptive forms of the L2.

At the same time, the point could be made that all prescriptive and non-prescriptive forms, both of their L1 and the target language, follow certain structure. It might be appropriate to introduce units in different areas of linguistic inquiry such as syntax, where phrase structure similarities/differences between languages/dialects can be analyzed to reach a better understanding of 1) how languages work, 2) what is universal among them, and 3) what is a specific feature of one or the other. This way, we could also introduce discussions around universality, markedness or even the innate nature of the language faculty. We could also include a unit on morphological analysis where they can compare the structure of words in their L1 and L2 and bring into awareness (or even develop) strategies for guessing the meaning of new words in the L2 by applying those that they might already be using in their L1.

In sum, a course designed to exploit the potential benefit of linguistics for language majors should have as its main objective the realization on the part of the student that 
language description extends far beyond their grammar texts. As such, this course needs to make use of every opportunity available, given the students' limited language background, to stimulate curiosity for a continuous study of the nature of language in general and of the target language in particular.

\subsection{Linguistics for (Native and Non-Native) Language Teachers}

It is not infrequent for native speakers of any language to believe that if they speak the language, they can teach it (Canagarajah, 1999; Faez, 2012; Phillipson, 1992). In fact, it is common for language departments to hire native speakers of the language with very little or no linguistic/pedagogical training at all. This popular belief that being a native speaker of a language provides a person with the necessary tools to teach the language is far from being accurate: Although untrained native speakers might have the grammatical intuitions or "authority" that second language learners lack, they are seldom metalinguistically aware of the rules that govern the language. Consequently, they need additional linguistic and pedagogical training that allows them to efficiently communicate their knowledge of the language to the learners.

In the case of non-native speakers, and as it was already noted in the 70 's, the misconception is that they can teach what they learned in the way they learned without any further linguistic training:

[M]any classroom teachers give little evidence of much, or any, exposure to concepts deriving from linguistics [....] many teachers of second languages do not know an allophone from a telephone, a grammatical transformation from an ecclesiastical reformation, or a sentence pattern from a holding pattern (Wardhaugh, 1972: 292-3).

Then, why do second language teachers still show such a deficiency in formal linguistic training (Andrews, 2006; Madrid and Pérez, 2004; Morin, 2007; Paradowski, 2008)? It seems that the root of the problem lies in the already traditional lack of communication between linguists and educators: While formal linguists "find the function of the language teacher irrelevant to the problem of understanding language" (Mack, 1990: 71) or "have doubts about the usefulness of their profession to language teaching" (Wu, 1992: 66), language teachers have felt for a long time that this type of formal training is not directly relevant for their job:

There is a tendency for educators to demand an immediate pay-off: if we can't apply these ideas directly here and now in our teaching, then we don't want anything to do with them. This attitude passes for a healthy pragmatism: we're practical people with a job to do, no time for the frills. In fact it is simply mental laziness - a refusal to inquire into things that may not have any immediate and obvious applications, but which for this very reason may have a deeper significance in the long run (Halliday, 1982: 15).

Although Halliday's observation is still very true 30 years later, many language teachers still think that knowledge of theoretical linguistics is irrelevant to their practice. But, "since 
language is both what L2 teachers teach and linguists describe [wouldn't it seem] self-evident that the findings of linguistics should be relevant to how the content of language courses is to be defined[?]" (Widdowson, 2000: 21). The question, then, is not whether language teachers should be trained in linguistics, but which aspects of linguistics should be emphasized in teacher training courses (Ellis, 2010). I agree that linguistics for teachers should not be "watered down" linguistics courses, but I also believe that language teaching is not linguistics any more than "medicine is chemistry". In this sense, we need to provide future language teachers with a good picture of what they are working with (language) and leave the rest alone. This might leave out discussions on current linguistic theory, but would emphasize the description of the different aspects of language included in any other linguistics-for-linguists course as well as the need to be up to date with relevant, applicable research.

\subsection{Linguistics for All: Elementary Literacy in Linguistics}

Everybody talks about language in an almost day-to-day basis. Each person has an opinion of what language is, and, most importantly, of what it should be like. For this reason, it is our responsibility as linguists to show our students how powerful language is and at the same time debunk some of the misconceptions that have been (and are) perpetuated by prescriptive linguistics and non-linguists alike.

In fact, and because linguists are often mistakenly identified as "language people" whose main aim is to teach low-level language courses, linguistics courses are frequently met with suspicion by colleagues "who question either the potential interest in such courses among students, or even their academic value ('Won't they learn all this anyway in a language class?' Er, no.)” (Hornsby, 2003: 11). However, and as I have been addressing throughout this article, linguistics brings an opportunity to prove, among other things, that 1) all varieties of a language (and all languages) are equally natural/systematic, and that 2) the reason why some enjoy a higher status than others is not of a linguistic nature, contrary to popular belief.

More than two decades ago, Hymes already proposed an "elementary 'literacy' in linguistics" course as part of general education for "every student of human life" (1992: 19). More recently, it has been proposed to include linguistics in primary and secondary education (Denham and Lobeck, 2010). In any case, as second language teachers, our moral duty is oftentimes to make students reflect not only on the language we are teaching, but on their native language as well. A theoretical course like this would serve as the foundation for any other course that deals with power relations: political science, cultural and ethnic studies, women and gender studies, anthropology, education, literature, communication studies, sociology, psychology, history... Since all of them deal at one point or another with power relations, and power relations have language at their core, all majors in these disciplines should have some form of theoretical linguistics as a general education requirement in the same fashion as math is usually required for a Bachelor's degree in science:

Such a curriculum [in linguistics] would help students better understand verbal presentations on all other cognitive disciplines and would also help them as citizens to recognize when they are verbally manipulated by a new Gorgias [.... [T]o train better scholars, to train better citizens, any curriculum must include a study of 
the exceptional capacity on which our entire species has built up its physiologic specificity (Thomas, 1998: 25-8)

In order to accommodate all students who might be interested in such a course (ideally at the freshman level), this course would 1) not have any pre-requisite, and 2) be offered in English (with data from various languages). Using data in multiple languages would serve a double purpose: it would prove that any language can be analyzed in a scientific, systematic way and it would become a way for language departments to attract future majors and minors.

\section{User-Friendly Approaches to the Teaching of Linguistics}

Linguistics does not enjoy a privileged or even popular place in language departments (a Google search (as of March 2012) with the keywords "linguistics" and "difficult" gives over 13 million hits). A possible reason for this might lie on the fact that most of our students do not find the motivation they need or feel threatened by the "pseudo-scientific flavor" of these courses:

To speak bluntly, it seems that when teaching linguistics [....], you first have to select the most irrelevant and uninteresting aspects of language, and then you proceed to teach them in the most unpalatable way that can be imagined. This obviously has to change, and here linguistics has a lot to learn from education, since our ways of teaching linguistics and grammar [....] have turned generations of teachers away from those vital areas of concern. Those that for some reason have managed to avoid rejecting linguistics have then proceeded to teach it to their own students in the same unpleasant way, thus compounding the problem (van Lier, 1994: 205).

In fact, many of our students leave the linguistics classroom without knowing how drawing syntactical trees or transcribing phonetically is going to be useful for them. However, if we go beyond mere tree-drawing or transcription and show them that they now have the tools to know the answers to (1) and (2) below, their attitude and motivation might change:

(1) Why is it possible to contract "want to" to "wanna" in a., but not in b.?

Where do you want to go? > Where do you wanna go?

Who do you want to go? $>$ *Who do you wanna go?

(2) Why can we pronounce a flap [r] in "atom" but not in "atomic"?

The list of examples like these in any language is endless. If we start an introductory course to linguistics with similar questions, we can rest assure that we will have piqued the interest of some of those initially unmotivated students.

Nonetheless, this is not the only way we can make linguistics accessible and relevant for students. As Pinker (1994) pointed out in the preface to his bestseller The Language Instinct: "I have never met a person who is not interested in language" (xiii). One way or another, most students in the humanities or social sciences can find one or more of the following uses of linguistics relevant for their career objectives: 
a. Linguistic inquiry in a second language helps the learner discover aspects of their native language they had never thought about.

b. Knowledge of linguistics poses a substantial advantage for improving language proficiency (and learning additional languages).

c. Knowledge of linguistics is crucial for gaining understanding of any other discipline in the humanities or social sciences.

d. Linguistic training helps teachers understand language development and why second language learners learn language the way they do (for example developmental errors vs. mistakes).

e. Linguistics helps us understand other cultures and other points of view that are reflected in language use, as well as our own.

f. Linguistics is fun.

As a consequence, an ideal introductory course in Linguistics should present not only a basic introduction to the main areas of linguistic inquiry (such as phonetics/phonology, morphology, syntax and semantics), but also to those areas that are intrinsically related to the former: sociolinguistics, pragmatics and discourse, first/second/multiple language acquisition, psicolinguistics... Finally, any other field that makes use of language for its purposes could be included as a final, practical component in the course: language and law, language of politics and advertisement, language and power...

The key factor when teaching these courses, as I have already pointed out, is that, in order to make the material accessible and engaging, we need to let the students take charge and discover the information by themselves. I suggest flooding the class with exercises in which students have to discover the rules underlying the target or any other language (known or unknown). The purpose of activities like these is to open students' minds into the vast array of linguistic principles that govern languages at the same time that they discover how similar languages are in many other respects.

One of the tasks for this course, for example, could be asking them to find the reason why Spanish-speakers have trouble with the voicing of $[z]$ in words like "zip" in English or why English speakers have trouble telling the difference between "todo" and "toro" in Spanish. As they pursue these tasks in languages that they speak, we can lead them to other examples in languages like Korean, where they can realize, for example, that lateral ([1]) and rhotic ([r]) liquids are allophones of the same phoneme in complementary distribution (they do not alternate freely). After they come up with the rule that explains the distribution of these two sounds in Korean, they will be able to explain why, although Korean speakers of English can pronounce "war" as "wall", contrary to popular belief, they will never pronounce "rice" as "lice". Working with this type of data will with no doubt prepare them to view language as a system and leave linguistic prejudices behind.

In sum, linguistics courses do not have to be lecture-oriented, boring and/or especially difficult. Courses in this area provide language majors, educators and any kind of student with invaluable insights into human nature and it is only by choosing the appropriate approach that we can guarantee an engaged audience. 


\section{Conclusion}

Learning to use a language for communication is very different from learning about the linguistic intricacies of that language. While many language majors enjoy studying a language, not many of them find theoretical linguistics as a worthy, valuable, easy-to-grasp subject with real-life applications. As a consequence, they shy away from it. Nevertheless, and as we have seen, students can become interested in the subject if we make them aware of its endless applications:

1) Upon graduation and in order to apply their knowledge of language to their career objective (be it as translators or as FBI consultants), language majors should be able to see language as more than a compilation of the prescriptive grammatical rules that can be found in traditional grammar texts.

2) Future language teachers are usually required to take language teaching methodology courses, but language teaching takes much more than speaking a language and knowing how to teach it: we need to know how language works as a system so we can make informed choices in our teaching. This way, language pedagogy, applied linguistics and theoretical linguistics are the three pillars of language teaching (Johnston and Goettsch, 2000).

3) Any student majoring in the humanities or social sciences could benefit from an elementary literacy in linguistics course because most disciplines in those areas will deal with language at some point.

My view is that, when we develop an innovative methodology that makes our courses "less user-hostile and more user-friendly" (Wei, 2007: 119) and when we teach linguistics in a "more exciting and inductive way" through open-ended questions and by letting students conduct their own investigations (Petray, 2004: 172), we will be in the right path to recognize the crucial role of linguistics in language programs.

\section{Bibliographical References}

ACTFL/NCATE. (2002). Program Standards for the Preparation of Foreign Language Teachers. Yonkers, NY: Author.

Andrews, S. (2006). "The evolution of teachers' language awareness", in Language Awareness, 15, 1: $1-19$.

Bolinger, D. (1968). "The theorist and the language teacher", in Foreign Language Annals, 2, 1 : 30-41. doi:10.1111/j.1944-9720.1968.tb00282.x

Canagarajah, A.S. (1999). "Interrogating the 'native speaker fallacy': Non-linguistic roots, nonpedagogical results", in G. Braine (ed.), Non-native Educators in English Language Teaching. Mahwah, N.J: Erlbaum, 77-92.

Correa, M. (2011). "La enseñanza de fonética y fonología a través de analogías y metáforas", in Hispania, 94, 2: 360-365. doi:10.1353/hpn.2011.0061

Cravens, T.D. (1996). "Linguistics in the curriculum", in Italica, 73, 4: 465-472.

Denham, K. and Lobeck, A. (eds.). (2010). Linguistics at School: Language Awareness in Primary and Secondary Education. Cambridge: Cambridge University Press. 
Ellis, E. M. (2012). "Language awareness and its relevance to TESOL", in University of Sydney Papers in TESOL, 7: 1-23.

Ellis, R. (2010). "Second language acquisition, teacher education and language pedagogy", in Language Teaching, 43, 2: 182-201. doi:10.1017/S0261444809990139

Faez, F. (2012). "Diverse teachers for diverse students: Internationally educated and Canadianborn teachers' preparedness to teach English language learners", in Canadian Journal of Education/Revue canadienne de l'éducation, 35, 3: 64-84.

Freeman, D. and Johnson, K.E. (1998). "Reconceptualizing the knowledge-base of language teacher education", in TESOL Quarterly, 32, 3: 397-417. doi:10.2307/3588114

Halliday, M. A. K. (1982). "Linguistics in teacher education", in R. Carter (ed.), Linguistics and the Teacher. London: Routledge and Kegan Paul, 10-15.

Hornsby, D. (2003). "Starting from scratch: French linguistics courses at Kent", in LLAS Occasional Papers, 11-12.

Hudson, R. (2003). "How can key skills 'sell' linguistics to students and employers?" in LLAS Occasional Papers, 3-8.

Hymes, D. (1992). "Inequality in language: Taking for granted", in Working Papers in Educational Linguistics, 8, 1: 1-30.

Ives, S. (1955). "Linguistics in the classroom", in College English, 17, 3: 165-172. doi: $10.2307 / 495740$

Johnston, B. and Goettsch, K. (2000). "In search of the knowledge base of language teaching: Explanations by experienced teachers", in Canadian Modern Language Review/ La Revue canadienne des langues vivantes, 56, 3: 437-468. doi:10.3138/cmlr.56.3.437

Mack, M. (1990). "Theoretical linguistics and applied linguistics research: Perspectives on their relationship to language pedagogy", in IDEAL, 5: 65-73.

Madrid, D. and Pérez Cañado, M.L. (2004). "Teacher and student preferences of native and nonnative foreign language teachers", in Porta Linguarum: revista internacional de didáctica de las lenguas extranjeras, 2: 125-138, available from http://www.ugr.es/local/portalin, accessed 21 December, 2012.

Morin, R. (2007). "A neglected aspect of the Standards: Preparing foreign language Spanish teachers to teach pronunciation", in Foreign Language Annals, 40, 2: 342-360. doi:10.1111/j.19449720.2007.tb03206.x

O’Neil, W. (1998). "Linguistics for everyone". Presented at the Applied Linguistic Association of Australia and Australian Linguistics Society, University of Queensland, Brisbane, available from http://emsah.uq.edu.au/linguistics/als/als98/oneil.html, accessed 28 September, 2011.

Paradowski, M.B. (2008). "ELF, ICC, and the N/NEST-the Challenges for English-Language Education in the 21st Century", in Proceedings of the 1st International Conference on English, Discourse and Intercultural Communication: 33-79. available from http://comm. louisville.edu/iic/books/mx11/MX_Volume\%20II_33-78_PARADOWSKI.pdf, accessed 13 February 2012.

Partington, A. (1992). "The teaching of linguistics in the L2 Medium". Presented at the 8th Institute of Language in Education International Conference, Hong Kong, available from http://eric.ed.gov/PDFS/ED374674.pdf, accessed 28 September, 2011.

Petray, M. J. (2004). Changing Linguistic Pedagogy: A Case Study of Five Introductory Linguistics Textbooks (Unpublished doctoral dissertation). Purdue University, West Lafayette, IN.

Phillipson, R. (1992). Linguistic Imperialism. Oxford: Oxford University Press. 
Pinker, S. (2007). The Language Instinct: How the Mind Creates Language. New York: Harper Perennial Modern Classics.

Pullum, G.K. (1991). The Great Eskimo Vocabulary Hoax and Other Irreverent Essays on the Study of Language. Chicago: University Of Chicago Press.

Spring, C.L., Flynn, M., Joseph, B.D., Moses, R., Steele, S. and Webb, C. (2000). "The successful introductory course: Bridging the gap for the nonmajor", in Language, 76, 1: 110-122. doi: $10.2307 / 417395$

Thomas, J.J. (1998). "Is there still a place for linguistics in the foreign language and literature curriculum?", in ADFL bulletin, 30, 1: 25-29.

Treffers-Daller, J. (2003). "Variation in teaching: two perspectives on teaching linguistics", in LLAS Occasional Papers, 12-14.

van Lier, L. (1994). "Educational linguistics: Field and project", in J.E. Alatis (ed.), Georgetown University Roundtable on Languages and Linguistics 1994. Washington, D.C.: Georgetown University Press, 199-209.

Wardhaugh, R. (1972). "TESOL: Our common cause", in TESOL Quarterly, 6, 4: 291-303. doi: $10.2307 / 3586157$

Wei, L. (2007). "A user-friendly linguistics", in International Journal of Applied Linguistics, 17, 1: 117-19. doi:10.1111/j.1473-4192.2007.00136.x

Widdowson, H.G. (2000). "Object language and the language subject: On the mediating role of applied linguistics", in Annual Review of Applied Linguistics, 20: 21-33. doi:10.1017/ S0267190500200020

$\mathrm{Wu}, \mathrm{W}$. (1995). "The education of second-language teachers: The link between linguistic theory and teaching practice", in J.E. Alatis, C.A. Straehle, B. Gallenberger and M. Ronkin (eds.), Georgetown University Round Table on Languages and Linguistics 1995. Washington D.C.: Georgetown University Press, 480-497. 